\title{
Arthrobacter phenanthrenivorans sp. nov., to accommodate the phenanthrene-degrading bacterium Arthrobacter sp. strain Sphe3
}

Correspondence

A. I. Koukkou

akukku@cc.uoi.gr

\author{
A. Kallimanis, ${ }^{1}$ K. Kavakiotis, ${ }^{1}$ A. Perisynakis, ${ }^{1}$ C. Spröer, ${ }^{2}$ R. Pukall, ${ }^{2}$ \\ C. Drainas ${ }^{1}$ and A. I. Koukkou ${ }^{1}$
}

${ }^{1}$ Sector of Organic Chemistry and Biochemistry, Department of Chemistry, University of loannina, 45110 loannina, Greece ${ }^{2} \mathrm{DSMZ}$ - Deutsche Sammlung von Mikroorganismen und Zellkulturen GmbH, Inhoffenstr. 7b,
D-38124 Braunschweig, Germany

\begin{abstract}
A novel phenanthrene-degrading bacterium, designated strain $\mathrm{Sphe}^{\top}$, was isolated from a creosote-contaminated soil in Greece. Cells were non-motile, Gram-positive, aerobic, and rod- to coccus-shaped. The strain was isolated on the basis of formation of a clear zone on agar plates sprayed with phenanthrene. Optimal growth occurred at $30{ }^{\circ} \mathrm{C}$. The $\mathrm{G}+\mathrm{C}$ content of the DNA was $65.7 \mathrm{~mol} \%$. The polar lipid pattern of strain $\mathrm{Sphe} 3^{\top}$ consisted of phosphatidylethanolamine, phosphatidylglycerol and diphosphatidylglycerol. The dominant fatty acids were iso- $\mathrm{C}_{15: 0 \text {, }}$ anteiso- $\mathrm{C}_{15: 0}$, iso- $\mathrm{C}_{16: 0}, \mathrm{C}_{16: 0}$ and anteiso- $\mathrm{C}_{17: 0}$, representing $>86 \%$ of the total fatty acids. The predominant isoprenoid quinone of strain $\mathrm{Sphe}^{\top}$ was menaquinone-8 (MK-8). Based on 16S rRNA gene sequence analysis, strain Sphe3 ${ }^{\top}$ showed 99 and $98.9 \%$ similarity to the type strains of Arthrobacter oxydans and Arthrobacter polychromogenes, respectively. Strain Sphe3 ${ }^{\top}$ showed $91 \%$ similarity to homologues of $A$. oxydans and $A$. polychromogenes based on rec $A$ gene sequence analysis. Based on 16S rRNA and recA gene sequence analysis and DNA-DNA hybridization analysis, as well as physiological and chemotaxonomic characteristics, it is concluded that strain $S p h e 3^{\top}$ represents a novel species of the genus Arthrobacter, for which the name Arthrobacter phenanthrenivorans sp. nov. is proposed. The type strain is Sphe3 ${ }^{\top}$ (=DSM

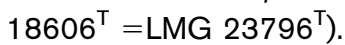

Polycyclic aromatic hydrocarbons (PAHs) are environmental pollutants that are found in many polluted soils as a result of natural or industrial activities, including those of creosote wood-treatment facilities (Mueller et al., 1989). PAHs have attracted considerable attention because of their potential toxicity for higher organisms and resistance to microbial degradation (Kanaly \& Harayama, 2000). A wide range of micro-organisms have been discovered that are able to degrade highly stable, toxic organic compounds such as polycyclic and aliphatic hydrocarbons (Habe \& Omori, 2003; Kanaly \& Harayama, 2000; Van Hamme et al., 2003). Among these micro-organisms, several Arthrobacter species are able to degrade PAHs (Grifoll et al., 1992; Seo et al., 2006). We have previously reported the phenanthrene uptake activity and membrane lipid alterations of a PAH-degrading Arthrobacter strain, Sphe3, isolated from a creosote-contaminated soil in Greece (Kallimanis et al.,

Abbreviation: PAHs, polycyclic aromatic hydrocarbons.

The GenBank/EMBL/DDBJ accession numbers for the 16S rRNA and recA gene sequences of strain Sphe $^{\top}$ are AM176541 and AM931439, respectively.
2007). In the present study, on the basis of phylogenetic analysis of $16 \mathrm{~S}$ rRNA and $r e c A$ gene sequences, together with physiological and chemotaxonomic characteristics and DNA-DNA hybridization analysis, we demonstrate that strain Sphe3 represents a novel species of the genus Arthrobacter.

Strain Sphe $3^{T}$ was isolated from Perivleptos, a creosotepolluted site in Epirus, Greece (12 km north of the city of Ioannina), in which a wood-preserving industry had operated for over 30 years (Kallimanis et al., 2007). Soil samples (10 g) were mixed with $100 \mathrm{ml}$ of minimal medium M9 (Sambrook et al., 1989) supplemented with $0.01 \%(\mathrm{w} / \mathrm{v})$ phenanthrene (in crystal form) as the sole carbon and energy source for growth. Following incubation at $30{ }^{\circ} \mathrm{C}$ for 1 week, the soil samples were serially diluted and screened for the presence of phenanthrene-degrading micro-organisms (Kiyohara et al., 1982; Zhang et al., 2004). Five colonies, able to grow in the presence of phenanthrene as the sole carbon source, were isolated and designated as Sphe3-Sphe8. As these organisms were all identified as belonging to the genus Arthrobacter based on preliminary 
16S rRNA gene sequence analysis, we selected the first isolate, strain Sphe3, for further characterization.

Cell morphology and motility were examined by using a microscope equipped with phase-contrast optics. Biochemical tests were performed as outlined by Smibert \& Krieg (1994) and Cappuccino \& Sherman (1996) at $37{ }^{\circ} \mathrm{C}$ in the appropriate medium. Appropriate positive and negative controls were included in all experiments. Formation of pigments characteristic of Arthrobacter polychromogenes or Arthrobacter oxydans was investigated on peptone-yeast agar plates or on nicotine agar $(0.4 \%$ nicotine) as described by Loveland-Curtze et al. (1999). The minimal inhibitory concentration of various antibiotics such as ampicillin, chloramphenicol, erythromycin, neomycin, rifampicin and tetracycline was estimated by growth tests on Luria agar medium.

Phospholipid and fatty acid methyl ester analyses were performed as described previously (Kallimanis et al., 2007, and references therein). Isoprenoid quinone extraction was performed as described by Rosa-Putra et al. (2001) and isoprenoid quinones were characterized by electrospray ionization mass spectrometry (ESI-MS).

DNA was isolated according to the standard Joint Genome Institute (JGI) protocol for bacterial genomic DNA isolation by using CTAB. The $16 \mathrm{~S}$ rRNA gene $(1.5 \mathrm{~kb})$ was amplified from the genomic DNA by using primers 16SF (5'-AGAGTTTGATCCTGGCTCAG-3') and 16SR $\left(5^{\prime}\right.$-AAGGAGGTGATCCAGCC-3') corresponding to Escherichia coli positions 9-27 and 1525-1542, respectively (Stackebrandt \& Liesack, 1993). Hot-start PCR at $95{ }^{\circ} \mathrm{C}$ for 5 min was followed by 30 cycles of $94{ }^{\circ} \mathrm{C}$ for $1 \mathrm{~min}, 60{ }^{\circ} \mathrm{C}$ for $2 \mathrm{~min}$ and $72{ }^{\circ} \mathrm{C}$ for $3 \mathrm{~min}$, and a final elongation step at $72{ }^{\circ} \mathrm{C}$ for $10 \mathrm{~min}$. Following electrophoresis on a $0.7 \%$ agarose gel, the amplified DNA fragment of $1.5 \mathrm{~kb}$ was purified by using a Nucleospin Extract II kit (MachereyNagel) and sequenced at Macrogen (Korea) by using primers $16 \mathrm{SF}$ and $16 \mathrm{SR}$.

The $\operatorname{rec} A$ gene sequence of strain $\mathrm{Sphe} 3^{\mathrm{T}}$ was provided by N. Kyrpides (personal communication); at the time of writing, sequencing of the genome of strain Sphe ${ }^{T}$ at the JGI had almost been completed.
For DNA-DNA hybridization, DNA was isolated by using a French pressure cell (Thermo Spectronic) and was purified by chromatography on hydroxyapatite as described by Cashion et al. (1977).

DNA-DNA hybridization was carried out as described by De Ley et al. (1970) under consideration of the modifications described by Huß et al. (1983) by using a model Cary 100 Bio UV/Vis spectrophotometer equipped with a Peltier-thermostatted $6 \times 6$ multicell changer and a temperature controller with in-situ temperature probe (Varian). Hybridization reactions were carried out in $2 \times$ SSC plus $10 \%$ formamide at $69{ }^{\circ} \mathrm{C}$.

The DNA G $+\mathrm{C}$ content was determined by the fluorimetric dye-binding method (Johnson, 1994) based on the differential binding of Hoechst 33258 (benzidine) and ethidium bromide to $\mathrm{A}+\mathrm{T}$ and $\mathrm{G}+\mathrm{C}$ regions of $\mathrm{DNA}$, respectively. E. coli $\mathrm{DH} 5 \alpha$ (52 mol\%), Agrobacterium tumefaciens UBAPF2 (60 mol\%) and Pseudomonas aeruginosa PAO (67 mol\%) were used as controls.

Taxonomic analysis was conducted by using the GenBank BLAST program. For phylogenetic and molecular evolutionary analysis, MEGA version 3.1 (Kumar et al., 2004) was used. The $16 \mathrm{~S}$ rRNA gene sequence of strain $\mathrm{Sphe} 3^{\mathrm{T}}$ (1500 bp) was aligned with sequences from related taxa by using the CLUSTAL W program (Thompson et al., 1994). The resultant tree topology was evaluated by bootstrap analysis by using the neighbour-joining method based on 1000 resamplings.

Strain Sphe ${ }^{\mathrm{T}}$ was found to be a Gram-positive, aerobic, non-motile bacterium exhibiting a rod-coccus cell cycle, with a cell size of approximately $1.0-1.5 \times 2.5-4.0 \mu \mathrm{m}$. Colonies were slightly yellowish on Luria agar. The temperature range for growth was $4-37{ }^{\circ} \mathrm{C}$ with optimum growth at $30-37{ }^{\circ} \mathrm{C}$. The $\mathrm{pH}$ range for growth was $6.5-8.5$ with optimal growth at $\mathrm{pH} 7.0-7.5$. Strain Sphe ${ }^{\mathrm{T}}$ was found to be sensitive to various antibiotics, the minimal inhibitory concentrations of which were estimated as follows: ampicillin, $20 \mathrm{mg} \mathrm{l}^{-1}$; chloramphenicol, $10 \mathrm{mg} \mathrm{l}^{-1}$; $\quad$ erythromycin, $10 \mathrm{mg} \mathrm{l}^{-1}$; neomycin, $20 \mathrm{mg} \mathrm{l}^{-1}$; rifampicin, $10 \mathrm{mg} \mathrm{l}^{-1}$; tetracycline, $10 \mathrm{mg} \mathrm{l}^{-1}$.

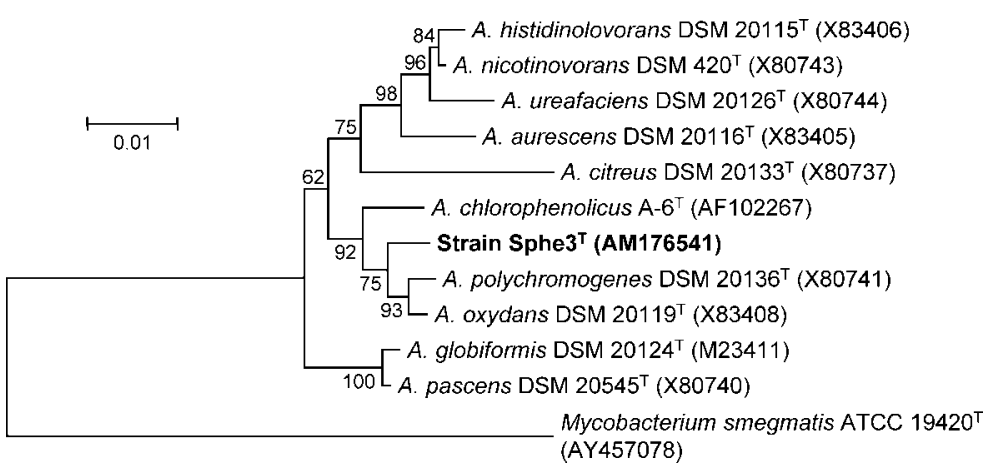

Fig. 1. Neighbour-joining phylogenetic tree showing the position of strain $\mathrm{Sphe}{ }^{\top}$ among closely related species of the genus Arthrobacter based on 16S rRNA gene sequences. Numbers at nodes are bootstrap percentages based on 1000 resamplings. Bar, 0.01 substitutions per nucleotide position. 


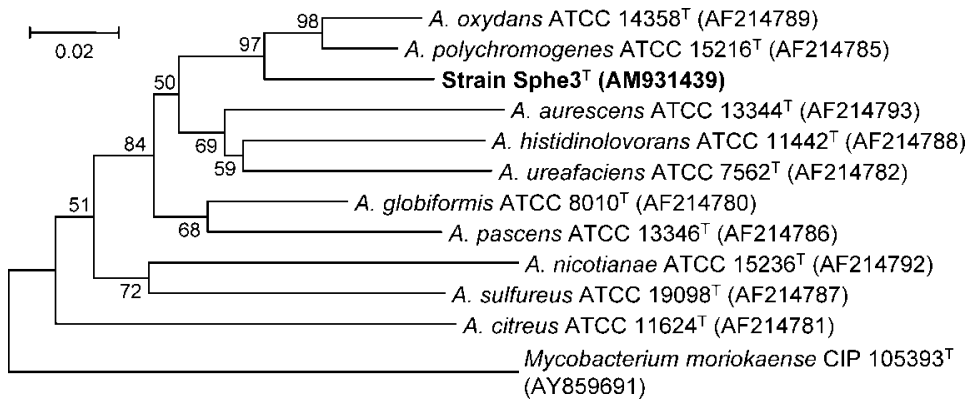

Fig. 2. Neighbour-joining phylogenetic tree showing the position of strain Sphe $3^{\top}$ among closely related species of the genus Arthrobacter based on recA gene sequences. Numbers at nodes are bootstrap percentages based on 1000 resamplings. Bar, 0.02 substitutions per nucleotide position.
Amylase, catalase and nitrate reductase tests were positive, whereas those for arginine dihydrolase, gelatinase, lipase, lysine and ornithine decarboxylases, oxidase, urease, citrate assimilation and $\mathrm{H}_{2} \mathrm{~S}$ production were negative. No acid was produced in the presence of glucose, lactose or sucrose. Strain Sphe $3^{\mathrm{T}}$ could also grow by utilizing anthracene (a three-ring $\mathrm{PAH}$ ) as carbon source, but not naphthalene (a two-ring aromatic hydrocarbon). Growth was also observed in the presence of 1-hydroxy-2-naphthoate, 2carboxybenzaldehyde, phthalate or protocatechuate, which constitute intermediate metabolites of the phenanthrene degradation phthalate pathway (Kiyohara \& Nagao, 1978; Barnsley, 1983). In addition, enzyme assays performed as described by Iwabuchi \& Harayama $(1997,1998)$ revealed activity of 1-hydroxy-2-naphthoate dioxygenase and 2carboxybenzaldehyde dehydrogenase (data not shown).

Strain Sphe $3^{T}$ contained menaquinones MK-8 and MK$9\left(\mathrm{H}_{2}\right)$ at a ratio of $3.6: 1$. Major fatty acids were anteiso$\mathrm{C}_{15: 0}(36.2 \%)$, iso- $\mathrm{C}_{16: 0}(15.7 \%)$, iso- $\mathrm{C}_{15: 0}(14.3 \%)$, anteiso- $\mathrm{C}_{17: 0}(12.0 \%), \mathrm{C}_{16: 0}(8.3 \%)$, iso- $\mathrm{C}_{17: 0}(4.0 \%)$, $\mathrm{C}_{16: 1} \omega 7 c(2.5 \%)$ and $\mathrm{C}_{14: 0}(1.4 \%)$. The major phospholipids were diphosphatidylglycerol, phosphatidylglycerol and phosphatidylethanolamine $(63.8,27.5$ and $4.0 \%$ respectively; data not shown).

The $\mathrm{G}+\mathrm{C}$ content of strain Sphe $3^{\mathrm{T}}$ was $65.7 \pm 0.2 \mathrm{~mol} \%$ (mean \pm SD of four determinations). This value is char- acteristic of recognized Arthrobacter species, which typically have a $\mathrm{G}+\mathrm{C}$ content in the range $59-70 \mathrm{~mol} \%$ (Keddie et al., 1986). The nucleotide sequence of $1520 \mathrm{bp}$ of the 16S rRNA gene of strain Sphe $3^{\mathrm{T}}$ was aligned with several homologues from other Arthrobacter species. Phylogenetic analysis was conducted by comparing the $16 \mathrm{~S}$ rRNA and recA genes from strain Sphe $3^{\mathrm{T}}$ with the corresponding genes from other representative taxa deposited in the GenBank database, and phylogenetic trees were constructed based on the neighbour-joining method (Figs 1 and 2). Comparative 16S rRNA gene sequence analysis showed that strain Sphe $3^{\mathrm{T}}$ was most closely related to the type strains of $A$. oxydans and $A$. polychromogenes (99 and $98.9 \%$ similarity, respectively). Alignment of the recA gene sequence of strain Sphe3 ${ }^{\mathrm{T}}$ with homologues of the above two species revealed $91 \%$ similarity. Table 1 details several phenotypic traits of strain Sphe ${ }^{\mathrm{T}}$ that could be used to differentiate it from phylogenetically related Arthrobacter species. Strain Sphe ${ }^{\mathrm{T}}$ was able to grow on nicotine but it differed from $A$. oxydans in that it did not form a blue pigment. Furthermore, unlike A. polychromogenes, strain $\mathrm{Sphe}^{\mathrm{T}}$ exhibited no blue pigmentation on carbohydrate peptone medium. In addition, $\operatorname{Sphe} 3^{\mathrm{T}}$ was able to grow in mineral salts medium, whereas $A$. oxydans and $A$. polychromogenes require vitamins such as biotin. Levels of DNA-DNA relatedness between strain Sphe3 ${ }^{\mathrm{T}}$ and its closest phylogenetic neighbours were $19.0 \%$

Table 1. Differential characteristics between strain $\mathrm{Sphe} 3^{\top}$ and its closest relatives in the genus Arthrobacter

Data for reference species were taken from Sguros (1955) (A. oxydans), Schippers-Lammertse et al. (1963) (A. polychromogenes) and Westerberg et al. (2000) (A. chlorophenolicus). NA, Not applicable; ND, no data available.

\begin{tabular}{|c|c|c|c|c|}
\hline Characteristic & Strain Sphe $3^{T}$ & A. oxydans & A. polychromogenes & A. chlorophenolicus \\
\hline Growth with nicotine & + & + & - & + \\
\hline \multicolumn{5}{|l|}{ Colony pigmentation on: } \\
\hline Nicotine agar & Cream to yellow & Blue & NA & Pearl grey \\
\hline Biotin requirement & - & + & + & - \\
\hline Temperature range $\left({ }^{\circ} \mathrm{C}\right)$ & $4-37$ & ND & $10-37$ & 3-37 \\
\hline Gelatinase & - & $+($ slow $)$ & $+($ rapid $)$ & $+($ slow $)$ \\
\hline Isolation source & Soil & Tobacco leaves and air & Airborne infection & Soil \\
\hline
\end{tabular}


(reciprocal value $28.2 \%$ ) with A. oxydans DSM $20119^{\mathrm{T}}$ and $42.3 \%(40.7 \%)$ with A. polychromogenes DSM $20136^{\mathrm{T}}$, clearly below the $70 \%$ considered to be the threshold value for the definition of bacterial species (Wayne et al., 1987).

On the basis of the data presented, we consider that strain Sphe $3^{\mathrm{T}}$ represents a novel species of the genus Arthrobacter, for which the name Arthrobacter phenanthrenivorans sp. nov. is proposed.

\section{Description of Arthrobacter phenanthrenivorans sp. nov.}

Arthrobacter phenanthrenivorans (phen.an'thre.ni.vo'rans. N.L. n. phenanthrenum phenanthrene; L. v. vorare to devour; L. part. adj. vorans devouring, digesting; N.L. part. adj. phenanthrenivorans digesting phenanthrene).

Cells are aerobic and non-motile, stain Gram-positive and exhibit a rod-coccus growth cycle. Colonies are cream to yellow in colour. Grows at $4-37{ }^{\circ} \mathrm{C}$ in mineral salts medium with a suitable carbon source; optimum growth occurs between 30 and $37{ }^{\circ} \mathrm{C}$. No additional growth factors are required. Catalase- and amylase-positive. Reduces nitrate to nitrite. Negative for oxidase, urease, lipase and gelatinase. Does not produce $\mathrm{H}_{2} \mathrm{~S}$. Acid is not produced from glucose, lactose or sucrose. Utilizes phenanthrene and anthracene as sole carbon sources. The major menaquinone is MK- 8 and the major fatty acids are anteiso- $C_{15: 0}$, iso- $\mathrm{C}_{16: 0}$, iso- $\mathrm{C}_{15: 0}$ and anteiso- $\mathrm{C}_{17: 0}$.

The type strain, Sphe3 ${ }^{\mathrm{T}}\left(=\mathrm{DSM} 18606^{\mathrm{T}}=\mathrm{LMG} 23796^{\mathrm{T}}\right)$, was isolated from creosote-contaminated soil in Greece.

\section{Acknowledgements}

We wish to thank Dr T. Sakellaridis and Dr A. Badeka for mass spectra of quinones obtained on an Agilent 1100 series LC-MSDTrap-SL spectrometer funded by the horizontal laboratory and Unit Centres of the University of Ioannina. This work was co-funded by the European Union within the framework of the program 'Pythagoras II' and by the Greek Secretariat for Research and Technology (Programme PENED 1999).

\section{References}

Barnsley, E. A. (1983). Phthalate pathway of phenanthrene metabolism: formation of 2' -carboxybenzalpyruvate. J Bacteriol 154, 113-117.

Cappuccino, J. G. \& Sherman, N. (1996). Microbiology: a Laboratory Manual, 4th edn. Menlo Park, CA: Benjamin/Cummings.

Cashion, P., Holder-Franklin, M. A., McCully, J. \& Franklin, M. (1977). A rapid method for base ratio determination of bacterial DNA. Anal Biochem 81, 461-466.

De Ley, J., Cattoir, H. \& Reynaerts, A. (1970). The quantitative measurement of DNA hybridization from renaturation rates. Eur $J$ Biochem 12, 133-142.

Grifoll, M., Casellas, M., Bayona, J. M. \& Solanas, A. M. (1992). Isolation and characterization of a fluorene-degrading bacterium: identification of ring oxidation and ring fission products. Appl Environ Microbiol 58, 2910-2917.
Habe, H. \& Omori, T. (2003). Genetics of polycyclic aromatic hydrocarbon metabolism in diverse aerobic bacteria. Biosci Biotechnol Biochem 67, 225-243.

Huß, V. A. R., Festl, H. \& Schleifer, K. H. (1983). Studies on the spectrophotometric determination of DNA hybridization from renaturation rates. Syst Appl Microbiol 4, 184-192.

Iwabuchi, T. \& Harayama, S. (1997). Biochemical and genetic characterization of 2-carboxybenzaldehyde dehydrogenase, an enzyme involved in phenanthrene degradation by Nocardioides sp. strain KP7. J Bacteriol 179, 6488-6494.

Iwabuchi, T. \& Harayama, S. (1998). Biochemical and molecular characterization of 1-hydroxy-2-naphthoate dioxygenase from Nocardioides sp. KP7. J Biol Chem 273, 8332-8336.

Johnson, J. L. (1994). Similarity analysis of DNAs. In Methods for General and Molecular Bacteriology, pp. 665-666. Edited by P. Gerhardt, R. G. E. Murray, W. A. Wood \& N. R. Krieg. Washington, DC: American Society for Microbiology.

Kallimanis, A., Frillingos, S., Drainas, C. \& Koukkou, A. I. (2007). Taxonomic identification, phenanthrene uptake activity, and membrane lipid alterations of the $\mathrm{PAH}$ degrading Arthrobacter sp. strain Sphe3. Appl Microbiol Biotechnol 76, 709-717.

Kanaly, R. A. \& Harayama, S. (2000). Biodegradation of highmolecular-weight PAHs by bacteria. J Bacteriol 182, 2059-2067.

Keddie, R. M., Collins, M. D. \& Jones, D. (1986). Genus Arthrobacter Conn and Dimmick 1947, 300 ${ }^{\mathrm{AL}}$. In Bergey's Manual of Systematic Bacteriology, vol. 2, pp. 1288-1301. Edited by P. H. A. Sneath, N. S. Mair, M. E. Sharpe \& J. G. Holt. Baltimore: Williams \& Wilkins.

Kiyohara, H. \& Nagao, K. (1978). The catabolism of phenanthrene and naphthalene by bacteria. J Gen Microbiol 105, 69-75.

Kiyohara, H., Kazutaka, N. \& Yana, K. (1982). Rapid screen for bacteria degrading water-insoluble, solid hydrocarbons on agar plates. Appl Environ Microbiol 43, 454-457.

Kumar, S., Tamura, K. \& Nei, M. (2004). MEGA3: integrated software for molecular evolutionary genetics analysis and sequence alignment. Brief Bioinform 5, 150-163.

Loveland-Curtze, J., Sheridan, P. P., Gutshall, K. R. \& Brenchley, J. E. (1999). Biochemical and phylogenetic analyses of psychrophilic isolates belonging to the Arthrobacter subgroup and description of Arthrobacter psychrolactophilus, sp. nov. Arch Microbiol 171, 355363.

Mueller, J. G., Chapman, P. J. \& Pritchard, P. H. (1989). Creosotecontaminated sites. Environ Sci Technol 23, 1197-1201.

Rosa-Putra, S., Hemmerlin, A., Epperson, J., Bach, T. J., Guerra, L. H. \& Rohmer, M. (2001). Zeaxanthin and menaquinone-7 biosynthesis in Sphingobacterium multivorum via the methylerythritol phosphate pathway. FEMS Microbiol Lett 204, 347-353.

Sambrook, J., Fritsch, E. F. \& Maniatis, T. (1989). Molecular Cloning: a Laboratory Manual, 2nd edn. Cold Spring Harbor, NY: Cold Spring Harbor Laboratory.

Schippers-Lammertse, A. F., Muijsers, A. O. \& Klatser-Oedekerk, K. B. (1963). Arthrobacter polychromogenes nov. spec., its pigments, and a bacteriophage of this species. Antonie van Leeuwenhoek 29, $1-15$.

Seo, J. S., Keum, Y. S., Hu, Y., Lee, S. E. \& Li, Q. X. (2006). Phenanthrene degradation in Arthrobacter sp. Pl-1: initial 1,2-, 3,4- and 9,10-dioxygenation, and meta- and ortho-cleavages of naphthalene-1,2-diol after its formation from naphthalene-1,2dicarboxylic acid and hydroxyl naphthoic acids. Chemosphere 65, 2388-2394.

Sguros, P. L. (1955). Microbial transformations of the tobacco alkaloids. J Bacteriol 69, 28-37. 
Smibert, R. M. \& Krieg, N. R. (1994). Phenotypic characterization. In Methods for General and Molecular Bacteriology, pp. 607-654. Edited by P. Gerhardt, R. G. E. Murray, W. A. Wood \& N. R. Krieg. Washington, DC: American Society for Microbiology.

Stackebrandt, E. \& Liesack, W. (1993). Nucleic acids and classification. In Handbook of New Bacterial Systematics, pp. 152-189. Edited by M. Goodfellow \& A. G. O’Donnell. London: Academic Press.

Thompson, J. D., Higgins, D. G. \& Gibson, T. J. (1994). CLUSTAL W: improving the sensitivity of progressive multiple sequence alignment through sequence weighting, position-specific gap penalties and weight matrix choice. Nucleic Acids Res 22, 4673-4680.

Van Hamme, J. D., Singh, A. \& Ward, O. P. (2003). Recent advances in petroleum microbiology. Microbiol Mol Biol Rev 67, 503-549.
Wayne, L. G., Brenner, D. J., Colwell, R. R., Grimont, P. A. D., Kandler, O., Krichevsky, M. I., Moore, L. H., Moore, W. E. C., Murray, R. G. E. \& other authors (1987). International Committee on Systematic Bacteriology. Report of the ad hoc committee on reconciliation of approaches to bacterial systematics. Int J Syst Bacteriol 37, 463-464.

Westerberg, K., Elvang, A. M., Stackebrandt, E. \& Jansson, J. K. (2000). Arthrobacter chlorophenolicus sp. nov., a new species capable of degrading high concentrations of 4-chlorophenol. Int J Syst Evol Microbiol 50, 2083-2092.

Zhang, H., Kallimanis, A., Koukkou, A. I. \& Drainas, C. (2004). Isolation and characterization of novel bacteria degrading polycyclic aromatic hydrocarbons from polluted Greek soils. Appl Microbiol Biotechnol 65, 124-131. 